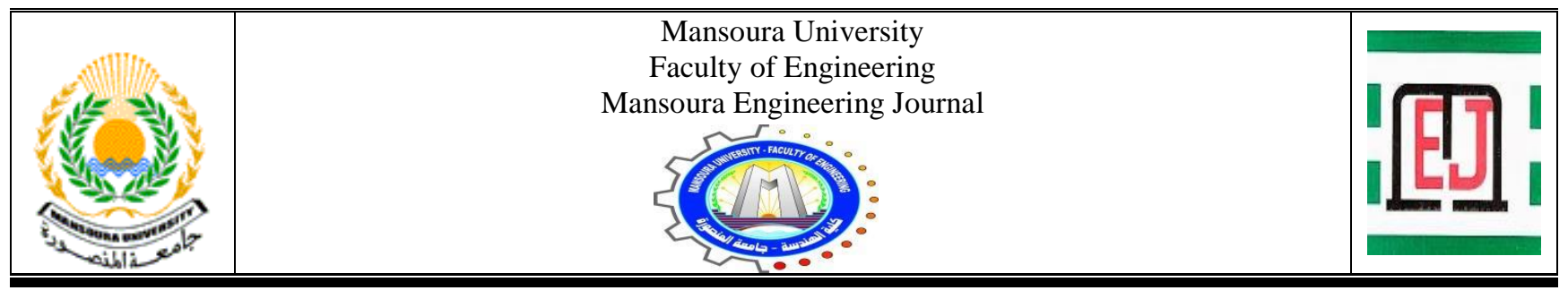

\title{
Compatibility between Canals Lining Methods and Sites Conditions Case Study: Al-Khofoog Canal, El-Minia
}

\author{
Tarek Sayed Abu-zeid
}

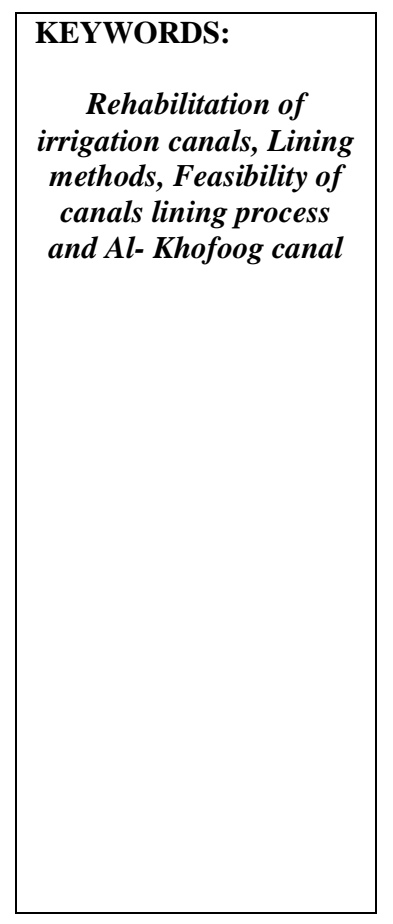

Abstract - The compatibility between the used methods of lining for open channels in permeable soils is the main indicator about the conservation efficiency of irrigation water, which means minimizing the quantities of water losses through the water transportation process. From this standpoint, and within the framework of the national project for the rehabilitation of irrigation canals in Egypt, which is implementing nowadays all over the villages of the Egyptian countryside, this work presents a field study for one of those canals for which the rehabilitation process is being implemented. The field study carried out in one of the Middle Egypt villages in the western desert, El-Minia governorate, to monitor the extent to which the lining being implemented with the proposed method is compatible with the nature of the canal's area, topography, soil types, groundwater levels, and so on. The case study that we are about to present, is for Al- Khofoog canal which is about $6.730 \mathrm{~km}$. long, engraved in a very fine sandy soil to irrigate about 6000 feddans. It was chosen due to the problems facing the implementing process, how to overcome and introduce the most suitable engineering treatments which may more compatible with the site properties and nature, supported by a quick economic feasibility study. This field study, that was conducted in the Middle Egypt region, is presented, hoping that it will be integrated with other similar studies to be conducted in other regions, representing North and South Egypt, for leading to develop a guideline, and a map includes the most appropriate rehabilitation methods in each region, according to its nature, and characteristics in that region in order to save effort, time, and money, maybe spent for implementing an unsuitable method, regardless of the site's privacy, nature, and expected problems.

\section{INTRODUCTION}

$\mathrm{O}$ pen channels lining process in permeable soils is essential for scoring more than one important goal. The first and most important goal is saving

Received: (07 June, 2021) - Revised: (23 June, 2021) - Accepted: (06 July, 2021)

Corresponding Author: Tarek Sayed Abu-zeid, Assistant Professor, Department of Civil Engineering, Assiut University, Assiut, Egypt (Email: tareksayed1986@aun.edu.eg; tareksayed1986@gmail.com ) great quantities of water that may be lost through seepage, and evaporation from the water surface area, which always exposed to increase due to the surfacing of the waterway sector. The second goal is the positive environmental impact on the cultural, health, and development pattern of the lifestyle in such regions. The third goal is to impose a new reality that maximizes the value of water and increases the sense of saving water among the beneficiaries, and the importance of preserving it in the light of the complex water shortage conditions that Egypt has been going through recently.

Through sharing Assuit University in the technical supervision, and follow up the implementation of the works of 
the national irrigation canals rehabilitation, all over the Egyptian countryside and their quality, the present study was carried out. In addition to the lining used methods, the study covers all related parameters that involved the irrigation water transportation losses and evaluates the reduction of such lost water through the lining process. The study also introduced a complete description of the region in which the under-study case is located, with analysis and description of the soil where the under-study case has been dug in, its natural properties, and mechanical characteristics.

After making the needed field visit, inspecting the site, inspecting the works that have been implemented, and by reviewing the engineering documents and panels for the works under-study, it was clear that the lining method to be implemented within the rehabilitation works for Al-Khofoog canal in western El-Minia is not commensurate with the nature of the site and the soil types. The study suggested three different technical solutions for the rehabilitation of that canal, more practicable, more efficient, and more economic, in addition to their suitability to site property, and soil condition.

\section{Literature REVIEW}

Nowadays due to the serious shortage in irrigation water, especially in arid and semiarid regions, scientists, and researchers have given a great attention to saving water for irrigation purposes. Since irrigation water is transported and distributed through a huge network of open channels, usually in permeable soil, a large part of its water is subject to be lost, either by deep seepage and leaching or by evaporation from the exposed water surface of those channels. Accordingly, many researchers have carried out many studies to reduce or prevent such losses, to meet the great shortage in irrigation water. Here, the most popular of these studies, and their results and conclusions will be reviewed and analyzed.

The loss of water by seepage from unlined canals generally varies from (30 to 50) percent of the discharge available at the head of an irrigation system. Seepage can be reduced up to 30 to $40 \%$ with lining but seepage cannot be controlled completely, [1]. The presence of cracks in the lining greatly reduces its effectiveness, [2]. According to British researchers, the seepage loss in a concrete-lined canal might be the same as an unlined canal if $0.01 \%$ of the lined area consists of cracks [3]. Shivakumar [4] also showed that canal lining with a $1 \%$ crack area has a seepage rate of $70 \%$ of that for unlined conditions. By lining the canal, the velocity of the flow can increase because of the smooth canal surface. For example, Karantz [5] showed that with the same canal bed slope and with the same canal size, the flow velocity in a lined canal is 1.5 to 2 times that in an unlined canal, which means that the canal cross-section in the lined canal is smaller to deliver the same discharge. According to Karantz [5] many possible benefits of lining such as water will be conserved, seepage of water into adjacent land or roads will be minimized, canal dimensions will be reduced and maintenance will also be reduced, [6].

Many materials, such as concrete, geomembrane, bitumen, and masonry, have been used to reduce seepage loss in canal lining. Concrete and geomembrane are commonly used in most countries, [7]. In China, seepage loss can be reduced by $52-55 \%$, according to the ponding test results on two canals before and after being lined with concrete for one year, [8]. Test results conducted in Pakistan by Snell [9] have shown that the seepage loss through unlined canals were reduced $75 \%$ and $97 \%$ soon after construction by concrete and geomembrane, respectively. According to the results of an inflow-outflow test conducted in Ethiopia, seepage loss from primary canals were reduced by $45.3 \%$ by the geomembrane lining, [10]. The new concrete and geomembrane lining combination presented by Xudong Han et al. [11] reduced seepage loss by $86 \%$ compared with no lining, while seepage loss reduced by $68 \%$ using the concrete and geomembrane lining combination after three service years.

According to Worstell [12] there are many factors that affect seepage from canals such as the texture of the soil in the canal bed and banks, soil chemicals, bank storage changes, siltation conditions, irrigation of adjacent fields, microbiological activity, water velocity, water temperature changes, evaporation, evapotranspiration and water table fluctuations. Proper design and construction of conveyance systems are necessary to minimize seepage, due to the limited available water supply and ever-increasing demand for water. Seepage is not only a waste of water, but it may also lead to other problems such as contamination of groundwater, waterlogging and salinization of agricultural land, rise in groundwater table leading to waste of useful land, reduction in irrigation efficiency, and increase in operational cost $[13,14,15]$

Seepage loss in permeable sandy soils may be as much as ten times that in tight soils and in heavy clay soils, it may be negligibly low. Soil types of canals are never completely uniform and will change with distance so will be the permeability rates [16]. The seepage loss from canals is governed by the hydraulic conductivity of the subsoil, canal geometry, hydraulic gradient between the canal and the aquifer underneath, and initial and boundary conditions.

The seepage loss from a canal in an unconfined flow condition is finite and maximum when the water table lies at a very high depth. The seepage loss from a canal in a homogeneous and isotropic porous medium, when the water table is at a very large depth, according to Swamee [17] can be expressed as:

$$
q_{s}=K y F
$$

Where $\mathrm{q}_{\mathrm{s}}$ is the seepage discharge per unit length of canal $\left(\mathrm{m}^{2} / \mathrm{s}\right) ; K$ is hydraulic conductivity of the porous medium $(\mathrm{m} / \mathrm{s})$; $y$ is the depth of water in the canal $(\mathrm{m})$, and $\mathrm{F}$ is the function of channel geometry (dimensionless). 


\section{Materials AND Methods}

\subsection{Description Of The Study Area:}

The study area is located about $196 \mathrm{~km}$. south of Cairo. This area located to the west of the Samalout area which extends to more than $35 \mathrm{~km}$ (north-south) and more than 10 $\mathrm{km}$ (west in the direction of the western desert). It extends approximately between longitudes $30^{\circ} 34^{\prime}$ and $30^{\circ} 40^{\prime}$ and latitudes $28^{\circ} 9^{\prime}$ and $27^{\circ} 29^{\prime}$. It covers a surface area of about 44000 Acres. The area has a dry climate, without rain in summer and with rare to mild precipitation in winter, with an annually averaged rainfall rate of about $5.3 \mathrm{~mm} / \mathrm{year}$. The annual average temperature is $21.3{ }^{\circ} \mathrm{C}$. The annual evaporation rate ranges from 1950 to $4000 \mathrm{~mm} /$ year. The annual mean of the relative humidity is $55 \%$, [18].

\subsection{Description Of The Site And Lining Works Of Al-Khofoog Canal:}

Al-Khofoog canal belongs to west El-Minia Irrigation Engineering Administration in El Minia, Egypt. It takes its share of water on the left bank of Manshyat Al-Dahab canal at $\mathrm{km} 46.180$ and its length is about $6.730 \mathrm{~km}$ as shown in figure (1). It serves an area of about 6000 feddans. The proposed length of the rehabilitation and lining process is $3.250 \mathrm{~km}$, starting from the $\mathrm{Km} \mathrm{0.0,} \mathrm{and} \mathrm{rehabilitation} \mathrm{works} \mathrm{were}$ carried out for a length of 560 meters only, starting from the $\mathrm{Km} 1.600$ by using rubble stone with a thickness of about 50 $\mathrm{cm}$, topped by a layer of plain concrete with a thickness of about $12 \mathrm{~cm}$ with side slopes of 3:2 as shown in figure (2), and with the necessary construction joints as shown in photo (1). Photo (2) shows the canal before lining.

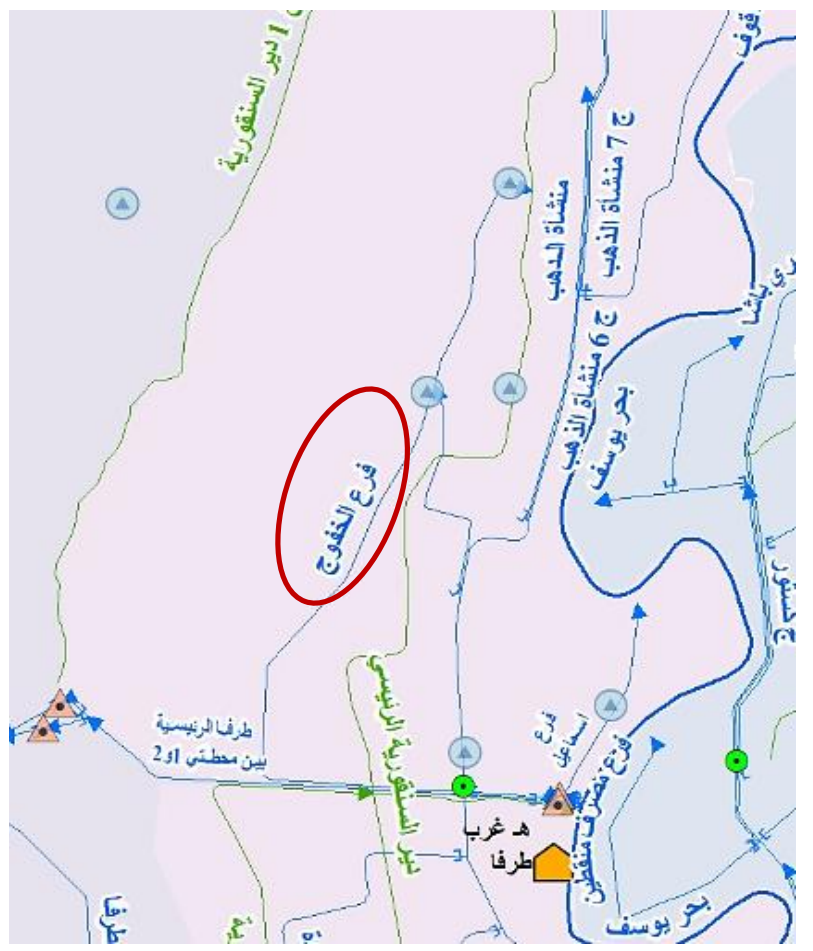

Fig. (1):Al-Khafoog canal map

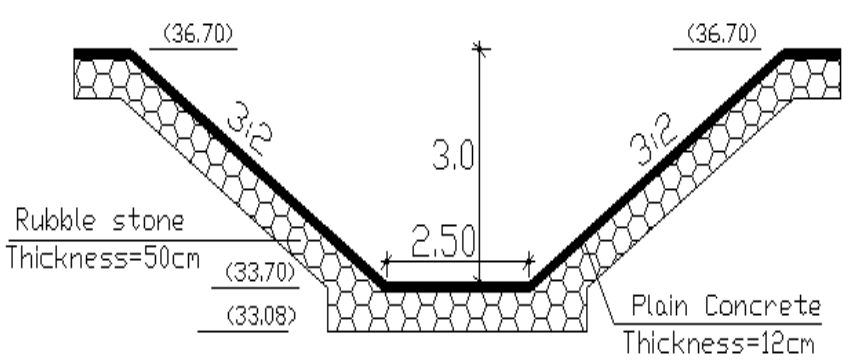

Fig. (2): The design cross-section of the Al-Khofoog canal (Km1.600 to $\mathrm{Km} 3.250$ )

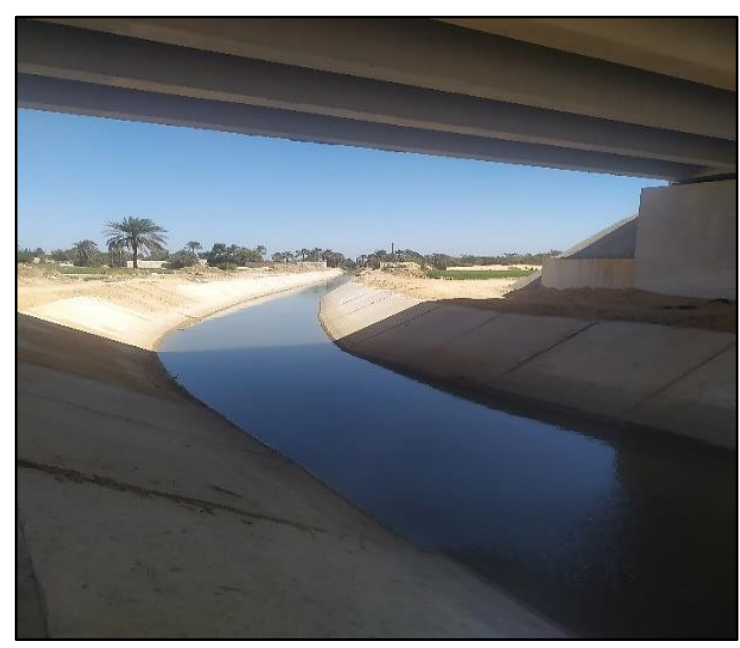

Photo (1): Lining works in the canal

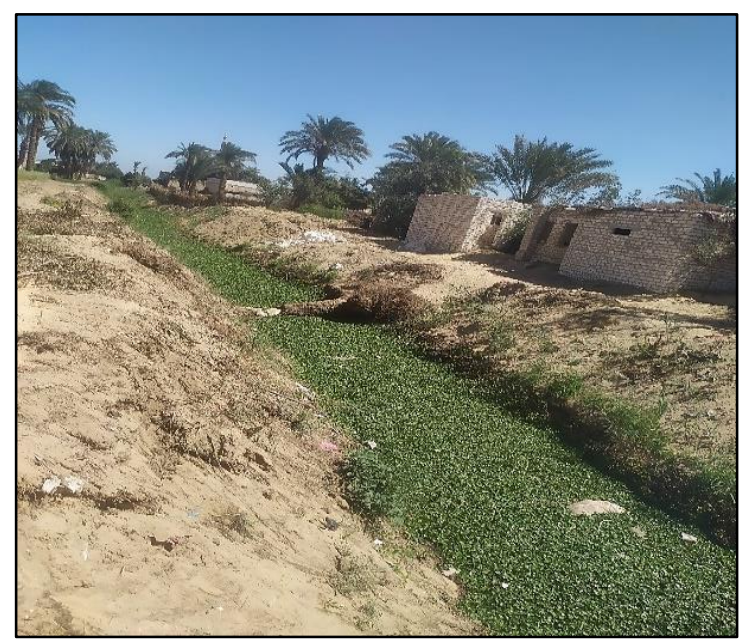

Photo (2): Unlined canal section

\subsection{Water seepage into the canal from the surrounding area:}

It was observed that there was seepage of water into the canal cross-section at a height of about $1.00 \mathrm{~m}$ above the bed level and sometimes it may reach about $1.50 \mathrm{~m}$, which causes great impediment during the implementation of the lining works, and the usage of large quantities of stone to be able to implement a regular concrete lining with the required thickness. To find out the source of this accumulated water, the gates of the intake of the canal were checked if they were 
open or not, or if there was a leakage permits the water to flow into the canal. It was observed that these gates were totally closed and that there was no leakage of water into the canal. By the topographical nature observation of the canal site with respect to the surrounding agricultural lands, it was found that the canal is in the lowest area in the region, which makes it a drain for those lands. It is worth mentioning that the water table in west El-Minia is very high, reaching in some places and sometimes the land surface. Accordingly, the cause of these amounts of water can be referred to that, in addition to the seepage of drainage water from the agricultural lands, which may affect the safety of the lining works. The following photos (3) and (4) show those amounts of seepage water in the canal section, and the surrounding agricultural lands.

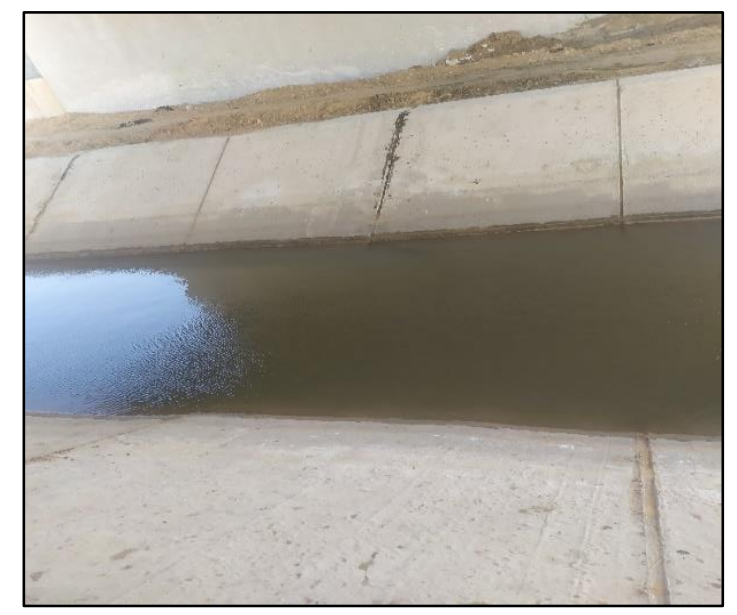

Photo (3): Water seepage into the canal

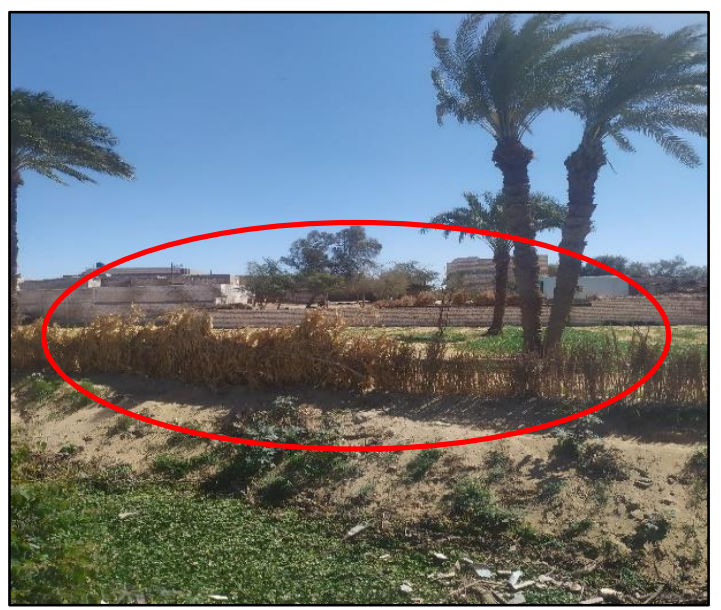

Photo (4): Buildings and lands near the canal

\subsection{Water Resources Around Al-Khofoog Canal:}

It was found that there is an adjacent canal called Tarfa canal, starting from $\mathrm{km} 0.00$ of the Al-Khafoog canal to $\mathrm{km}$ 1.500 as shown in figure (1). The levels of the two canals are shown in figure (3), which shows a difference in height between the Tarfa canal water level and the unlined bed level of the Al-Khafoog canal, reaching to about $2.30 \mathrm{~m}$, which is a large difference that may cause further seepage of water into the canal cross-section.

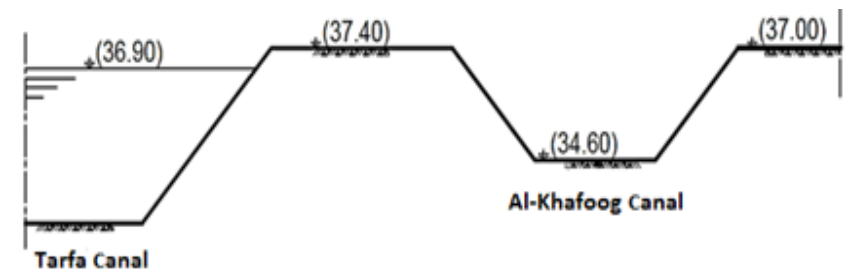

Fig. (3): Cross-sections of the Al-Khofoog canal (without lining) and Tarfa canal

\subsection{Soil Problems:}

There were some failures in the bed slabs due to the large amounts of seepage water into the canal cross-section. It was also noticed that there was sliding and failure in some of the side-lined slabs, as well as some failures of the canal slopes in places that have not been lined, as shown in photos (5) and (6).

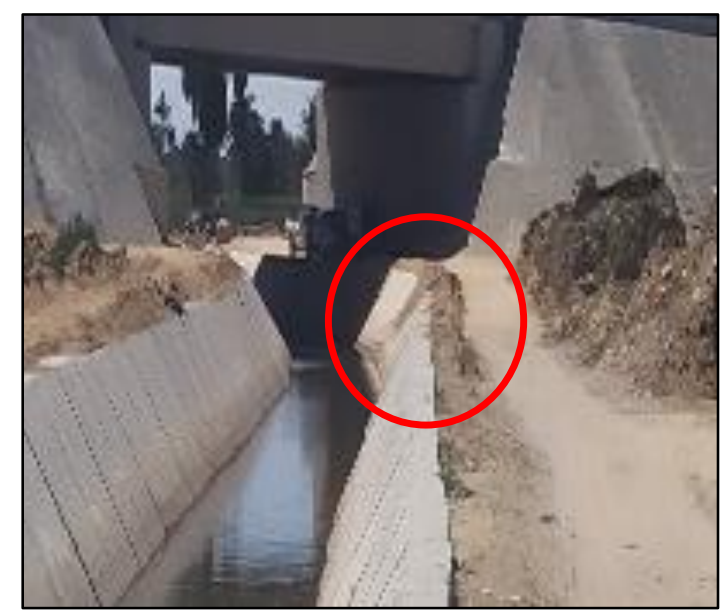

Photo (5): Sliding in some lined slabs

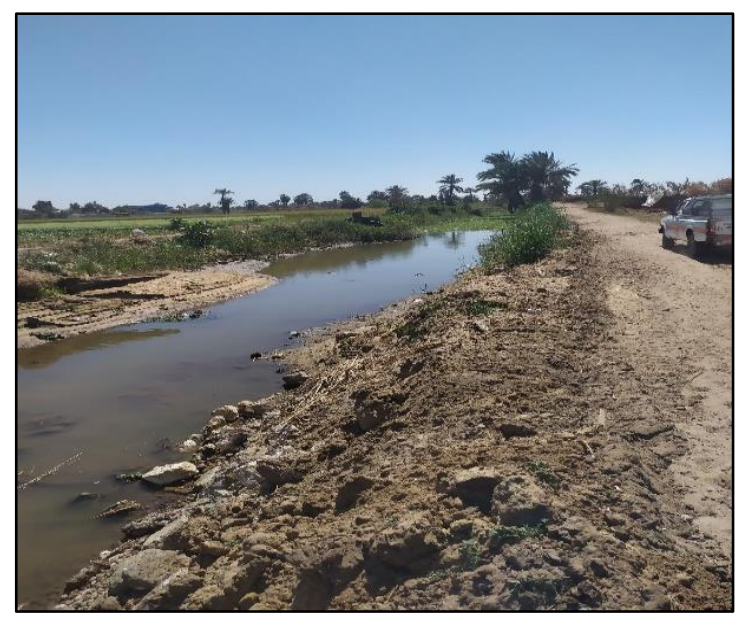

Photo (6): Failure of canal side slopes

\subsection{Soil Analysis:}

From soil observation and tests, it was found that the soil, which was taken from different places and at different depths 
under the bed of the canal and from the side slopes, consists of fine sand with a small percentage of silt with a depth of $1.00 \mathrm{~m}$ from the land surface, followed by a layer of fine light-colored sand, up to a depth of $4.00 \mathrm{~m}$ below the land surface and the water table was at a depth of about 2.00 below the land surface, as shown in figure (4).

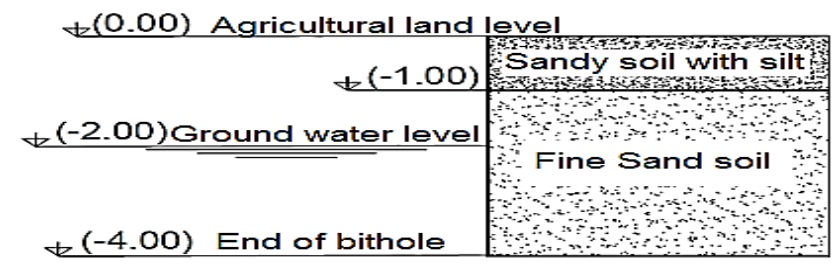

Fig. (4): Soil classification in the site

The soil, according to the samples taken from the site, is very fine soil with a small internal failure angle, so a slope of 3:2 may be not suitable with its nature and it would be better if the side slopes in such soils were 2:1 to ensure more stability of slopes and avoid such failures.

For the slope-stability assessment, the factor of safety for these two cases of slopes was calculated as shown in figure (5) as an example, to ensure the suitability of these slopes with the site conditions as follow:

$$
F . S=\frac{M_{\text {stabillity }}}{M_{\text {over truning }}}=\cdots . . \nless 1.50
$$

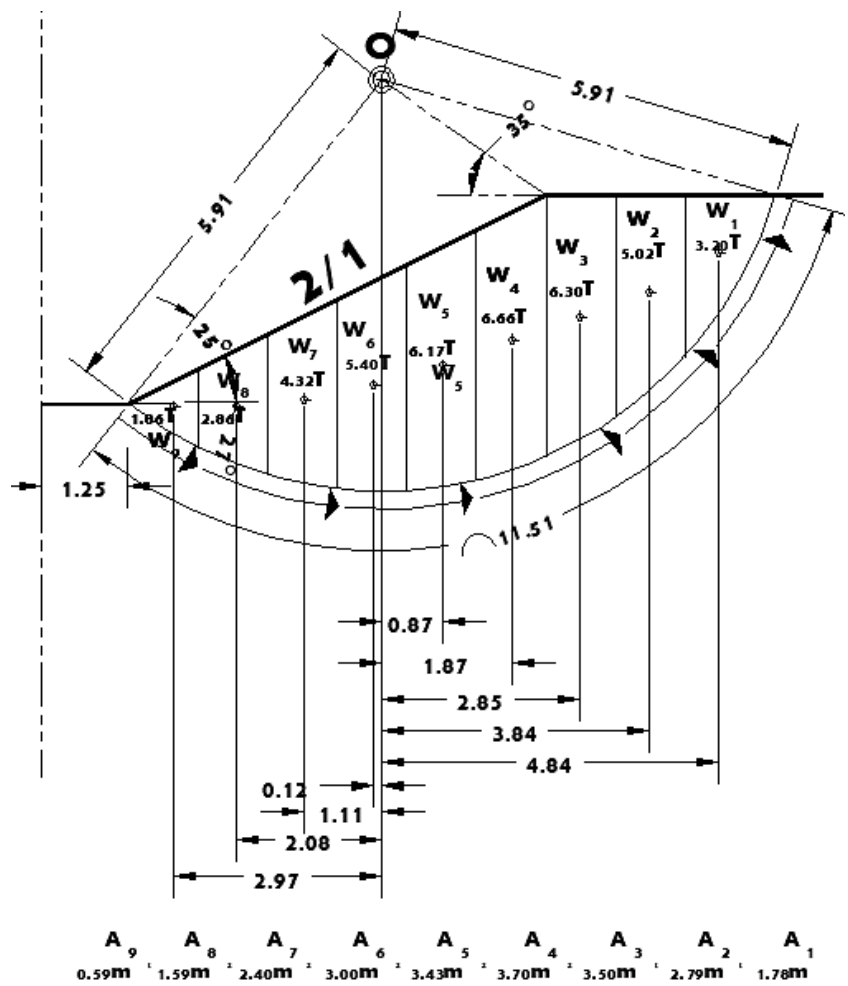

Fig. (5): The slope stability for the case of (slope 2:1), as an example

According to the above equation, it found that the factor of safety equals 1.47 and 1.70 for the slope of $3: 2$ and $2: 1$ respectively. So, the slope of $2: 1$ is more stable because the failure of the slope in the working area can give rise to significant economic losses and safety impact.

\subsection{Structural Safety, And Stability Of Slopes:}

Based on the design cross-sections of the canal after lining using $50 \mathrm{~cm}$ of rubble topped by a layer of plain concrete with a thickness of about $12 \mathrm{~cm}$, with side slopes 3:2 as shown in figure (2), is not suitable with site conditions, such as the soil type, the high groundwater levels and the large amounts of water which make many difficulties during the lining works. It is necessary to study the possibility of using another method for the lining process to be more appropriate to the nature of the site due to the lack of feasibility of the proposed method in such conditions.

\section{RESUlTS AND DISCUSSION}

Based on the above analysis, three alternative engineering methods could be suggested for the lining process which may be more suitable for site conditions

\section{The First Method:}

Covering the canal with a reinforced concrete pipe of appropriate diameter for the required discharge, as shown in figure (6).

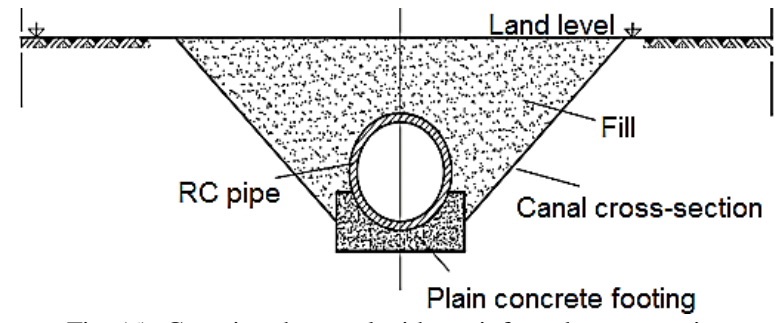

Fig. (6): Covering the canal with a reinforced concrete pipe

\section{The Second One:}

Constructing a rectangle cross-section of reinforced concrete walls with the appropriate thickness, and drainage pipes with non-return valves on both sides of the canal, as shown in figure (7).

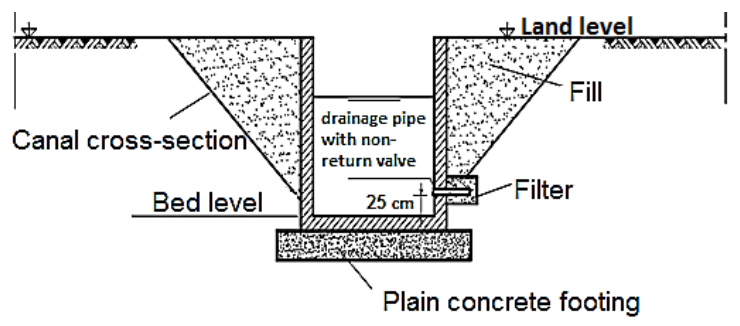

Fig. (7): Constructing a rectangle cross-section of reinforced concrete walls

\section{The Third Method:}

Using walls of the rubble with cement mortar to form the canal cross-section and lining it with a layer of lightly reinforced concrete with a thickness of $10 \mathrm{~cm}$ on the bed and sides, and drainage pipes with non-return valves on both sides of the canal, as shown in figure (8). 


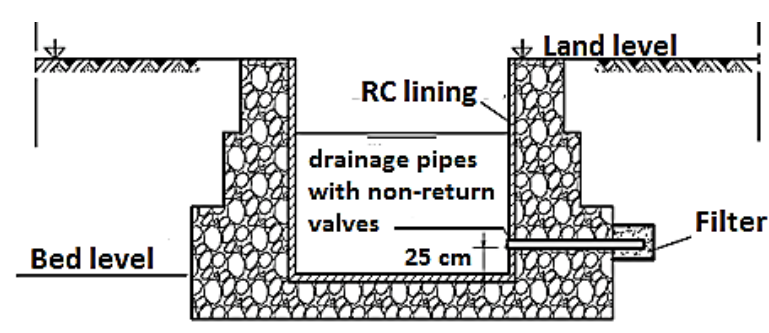

Fig. (8): Using walls of the rubble with cement mortar to form the canal cross-section

To make the hydraulic comparison between the suggested alternative engineering methods for the lining process, tables $1,2,3$, and 4 show the dimensions, characteristics, velocity, and discharges of the different sections of Al-Khofoog canal in the case of (Designed sections) and the three introduced alternatives.

Manning equation is used for calculating the discharges of canal for the different cases as given in the tables 1,2,3, and 4. Manning equation could be written as:

$$
Q=\frac{1}{n} \times R^{\frac{2}{3}} \times S^{0.5} \times A
$$

Where Q: water discharge $\left(\mathrm{m}^{3} / \mathrm{s}\right)$, S: Long. Slope $(\mathrm{m} / \mathrm{m})$, $\mathrm{R}$ : hydraulic radius (m), and A: area of hydraulic section $\left(\mathrm{m}^{2}\right)$.

\subsection{Hydraulic Comparison Between The Three Suggested Engineering Methods:}

TABLE 1

\begin{tabular}{|c|c|c|c|c|c|c|}
\hline Section & $\begin{array}{l}\text { Bed width } \\
\text { (m) }\end{array}$ & $\begin{array}{c}\text { Water depth } \\
\text { (m) }\end{array}$ & $\begin{array}{c}\text { Manning } \\
\text { coefficient (n) }\end{array}$ & $\begin{array}{l}\text { Long. water } \\
\text { Slope (-) }\end{array}$ & $\begin{array}{c}\text { Velocity } \\
(\mathrm{m} / \mathrm{s})\end{array}$ & $\begin{array}{c}\text { Discharge } \\
\left(\mathrm{m}^{3} / \mathbf{s}\right)\end{array}$ \\
\hline$K m(0.00: 1.600)$ & 4.0 & 1.50 & 0.025 & $5 * 10^{-5}$ & 0.282 & 2.645 \\
\hline$K m(1.600: 3.250)$ & 2.50 & 1.50 & 0.025 & $5 * 10^{-5}$ & 0.264 & 1.879 \\
\hline$K m(3.250: 5.180)$ & 2.0 & 1.50 & 0.025 & $5 * 10^{-5}$ & 0.256 & 1.631 \\
\hline$K m(5.180: 6.730)$ & 1.50 & 1.50 & 0.025 & $5 * 10^{-5}$ & 0.247 & 1.387 \\
\hline
\end{tabular}

TABLE 2

DIMENSIONS, CHARACTERISTICS, VELOCITY, AND DISCHARGES OF THE DIFFERENT SECTIONS OF AL-KHOFOOG CANAL (THE FIRST METHOD)

\begin{tabular}{|c|c|c|c|c|c|c|}
\hline Section & $\begin{array}{c}\text { Pipe } \\
\text { Diameter } \\
(\mathbf{m})\end{array}$ & $\begin{array}{c}\text { Water depth } \\
\text { (m) }\end{array}$ & $\begin{array}{c}\text {.Manning } \\
\text { coefficient (n) }\end{array}$ & $\begin{array}{l}\text { Long. water } \\
\text { Slope (-) }\end{array}$ & $\begin{array}{c}\text { Velocity } \\
(\mathrm{m} / \mathrm{s})\end{array}$ & $\begin{array}{c}\text { Discharge } \\
\left(\mathrm{m}^{3} / \mathrm{s}\right)\end{array}$ \\
\hline $\mathrm{Km}(0.00: 1.600)$ & 2.0 & 1.50 & 0.0143 & $25 * 10-5$ & 1.049 & 2.645 \\
\hline$K m(1.600: 3.250)$ & 2.0 & 1.50 & 0.0143 & $25 * 10-5$ & 0.745 & 1.879 \\
\hline $\operatorname{Km}(3.250: 5.180)$ & 2.0 & 1.50 & 0.0143 & $16 * 10-5$ & 0.645 & 1.631 \\
\hline $\operatorname{Km}(5.180: 6.730)$ & 2.0 & 1.50 & 0.0143 & $12 * 10-5$ & 0.548 & 1.387 \\
\hline
\end{tabular}

TABLE 3

DIMENSIONS, CHARACTERISTICS, VELOCITY, AND DISCHARGES OF THE DIFFERENT SECTIONS OF AL-KHOFOOG CANAL (THE SECOND METHOD)

\begin{tabular}{c||c||c||c||c||c||c} 
Section & $\begin{array}{c}\text { Bed width } \\
(\mathbf{m})\end{array}$ & $\begin{array}{c}\text { Water depth } \\
(\mathbf{m})\end{array}$ & $\begin{array}{c}\text { Manning } \\
\text { coefficient }(\mathbf{n})\end{array}$ & $\begin{array}{c}\text { Long. water } \\
\text { Slope }(-)\end{array}$ & $\begin{array}{c}\text { Velocity } \\
(\mathbf{m} / \mathbf{s})\end{array}$ & $\begin{array}{c}\text { Discharge } \\
\left(\mathbf{m}^{3} / \mathbf{s}\right)\end{array}$ \\
\hline$K m(0.00: 1.600)$ & 2.80 & 1.50 & 0.0143 & $10^{*} 10^{-5}$ & 0.629 & 2.645 \\
\hline$K m(1.600: 3.250)$ & 2.15 & 1.50 & 0.0143 & $10^{*} 10^{-5}$ & 0.581 & 1.879 \\
\hline$K m(3.250: 5.180)$ & 1.95 & 1.50 & 0.0143 & $10^{*} 10^{-5}$ & 0.561 & 1.631 \\
\hline$K m(5.180: 6.730)$ & 1.75 & 1.50 & 0.0143 & $10^{*} 10^{-5}$ & 0.537 & 1.387
\end{tabular}

TABLE 4

DIMENSIONS, CHARACTERISTICS, VELOCITY, AND DISCHARGES OF THE DIFFERENT SECTIONS OF AL-KHOFOOG CANAL (THE THIRD METHOD)

\begin{tabular}{c||c||c||c||c||c||c} 
Section & $\begin{array}{c}\text { Bed width } \\
(\mathbf{m})\end{array}$ & $\begin{array}{c}\text { Water depth } \\
(\mathbf{m})\end{array}$ & $\begin{array}{c}\text { Manning } \\
\text { coefficient }(\mathbf{n})\end{array}$ & $\begin{array}{c}\text { Long. water } \\
\text { Slope }(-)\end{array}$ & $\begin{array}{c}\text { Velocity } \\
(\mathbf{m} / \mathbf{s})\end{array}$ & $\begin{array}{c}\text { Discharge } \\
\left(\mathbf{m}^{\mathbf{3}} / \mathbf{s}\right)\end{array}$ \\
\hline$K m(0.00: 1.600)$ & 2.90 & 1.50 & 0.0149 & $10^{*} 10^{-5}$ & 0.608 & 2.645 \\
\hline$K m(1.600: 3.250)$ & 2.25 & 1.50 & 0.0149 & $10^{*} 10^{-5}$ & 0.562 & 1.879 \\
\hline$K m(3.250: 5.180)$ & 2.00 & 1.50 & 0.0149 & $10^{*} 10^{-5}$ & 0.542 & 1.631 \\
\hline$K m(5.180: 6.730)$ & 1.75 & 1.50 & 0.0149 & $10^{*} 10^{-5}$ & 0.521 & 1.387
\end{tabular}




\section{For the first method:}

- Reinforced concrete pipes with a diameter of $2.0 \mathrm{~m}$ were used for the entire length of the canal, with different longitudinal slopes as shown in table (2). The velocity in the different sectors ranged between 0.548 and $1.049 \mathrm{~m} / \mathrm{s}$, to keep the discharge values in the canal constant as in the design sections. Noting that the water depth in the canal is within $1.5 \mathrm{~m}$ and therefore the flow inside the pipe is an open channel flow. Froude number for the flow inside the pipe was also calculated, and it ranged between 0.14 and 0.27 , which means that the flow is subcritical. Also, the diameter of the pipe has been fixed $(\mathrm{D}=2.0 \mathrm{~m})$ to facilitate the implementation process in nature.

\section{For the second method:}

- Reinforced concrete walls with a height of $3.0 \mathrm{~m}$ and a thickness of $30 \mathrm{~cm}$ were used for the entire length of the canal, with the use of different bottom widths according to the discharge values as shown in table (3). Also, the flow velocity is more than 2.0 times that in an unlined canal.

\section{For the third method:}

- Rubble walls were used, with a height of $3.0 \mathrm{~m}$ and a thickness of $75 \mathrm{~cm}$ from the top, increasing by $25 \mathrm{~cm}$ as the depth increases by $1 \mathrm{~m}$ over the entire length of the canal with the use of different widths of the bottom according to the discharge values as in table (4). Also, the flow velocity is more than 2.0 times that in the earthen sections of the canal.

Hydraulically, the three suggested alternatives methods are suitable and the velocities are within the limits permitted in open channels. Therefore, an economic feasibility study will be conducted to choose between the three suggested alternatives.

\subsection{Economic comparison and feasibility study:}

For ensuring the feasibility of using the suggested alternative engineering methods economically, a quick feasibility study was conducted on the basis of prevailing prices in the local market at the present time. The following table shows the quantities and the total cost of the different categories used with the suggested three alternative methods according to the average prices of three contracting companies in Egypt as follow:

\section{For the first method:}

- The price per one-meter length of reinforced concrete pipe with a diameter of 2.0 meters, including excavation works, the refinement of the canal cross-section, plain concrete, reinforced concrete, connections, irrigation rooms, backfilling, compaction works, afforestation, building a fence, metal works, and building entrances and exits from the rubble, will be 13000 .

\section{For the second method:}

- The price per one cubic meter of plain concrete works for foundations consisting of sand, aggregate, and cement, at a ratio of $0.4 \mathrm{~m}^{3}$ sands: $0.8 \mathrm{~m}^{3}$ gravel: $250 \mathrm{~kg}$ of Portland cement resistant to sulfates, including excavation, support the sides of the drilling to reach the design level, filters, surface or deep dewatering work to pour concrete in complete dryness, backfill with clean sandy soil, and compaction works, will be 1750 LE.

- The price per one cubic meter of reinforced concrete works consisting of sand, aggregate, and cement, at a ratio of 0.4 $\mathrm{m}^{3}$ sands: $0.8 \mathrm{~m}^{3}$ gravel: $350 \mathrm{~kg}$ of Portland cement resistant to sulfates, including chopping works, wooden or metal wrenches, filters, drainage pipes with non-return valves, installing metal stairs, and construction joints, will be 4300 LE.

\section{For the third method:}

- The price per one cubic meter of pitching works loaded with excavation, the refinement of the canal cross-section, building works of the rubble with cement mortar, support the sides of the drilling to reach the design level, surface or deep dewatering work to constructing walls in complete dryness, backfill with clean sandy soil, and compaction works, will be $650 \mathrm{LE}$.

- The price per one cubic meter of reinforced concrete works consisting of sand, aggregate, and cement, at a ratio of 0.4 $\mathrm{m}^{3}$ sands: $0.8 \mathrm{~m}^{3}$ gravel: $350 \mathrm{~kg}$ of Portland cement resistant to sulfates, including chopping works, wooden or metal wrenches, filters, drainage pipes with non-return valves, installing metal stairs, and construction joints, will be $4300 \mathrm{LE}$.

TABLE 5

COMPARATIVE TABLE FOR THE INTRODUCED THREE ALTERNATIVE METHODS FOR THE LINING PROCESS

\begin{tabular}{|c|c|c|c|c|c|}
\hline Alternative & Category & Quantity & $\begin{array}{c}\text { Price per } \\
\text { unit } \\
\text { L.E. }\end{array}$ & $\begin{array}{l}\text { Cost } \\
\text { L.E. }\end{array}$ & $\begin{array}{l}\text { Total cost in } \\
\text { pounds L.E. }\end{array}$ \\
\hline $\begin{array}{l}\text { The first } \\
\text { suggested method }\end{array}$ & $\begin{array}{l}\text { Reinforced concrete pipe with a diameter } \\
\text { of } 2.00 \ldots \ldots \text { etc) }\end{array}$ & $\begin{array}{l}6730 \mathrm{~m} \text { of } \\
\mathrm{D}=2.00 \mathrm{~m}\end{array}$ & 13000 & 87,490000 & 87,490000 \\
\hline \multirow{2}{*}{$\begin{array}{l}\text { The second } \\
\text { suggested method }\end{array}$} & $\begin{array}{l}\text { Plain concrete works for foundations } \\
\text {........etc }\end{array}$ & $12299.25 \mathrm{~m}^{3}$ & 1750 & 21,523688 & \multirow{2}{*}{88,499413} \\
\hline & Reinforced concrete works .....etc) & $15575.75 \mathrm{~m}^{3}$ & 4300 & 66,975725 & \\
\hline \multirow{2}{*}{$\begin{array}{l}\text { The third } \\
\text { suggested method }\end{array}$} & Pitching works loaded .......etc) & $69913 \mathrm{~m}^{3}$ & 650 & 45,443450 & \multirow{2}{*}{71,539720} \\
\hline & Reinforced concrete works of sand,...etc) & $6068.9 \mathrm{~m}^{3}$ & 4300 & 26,096270 & \\
\hline
\end{tabular}


From the above comparative table, it is clear that the third alternative suggested method is the less cost, while the second suggested method is the highest one. Also, the cost of implementing of one kilometer for the three alternatives are 13.0, 13.14, and 10.62 million LE respectively.

\section{Conclusions}

From the above-presented work and analysis, the following main conclusions can be drawn:

a) This study proved that implementing unified models using specific engineering designs and methods for rehabilitating, without considering the site's specificity and nature does not necessarily give the best results.

b) It is of great importance to conduct initial exploratory studies for different surrounding areas of the project, in preparation for producing a guide technical map for each region for recommending the proper methods to be carried out.

c) Proposed internal side slopes of Al-Khafoog canal crosssection under implementation (3:2) is unsuitable for the existing type of soil in the field and must be changed to be $(2: 1)$ which is more suitable and compatible with the soil type for more stability of slopes.

d) The large amounts of seepage water from the surrounding high lands into Al-Khafoog canal cross sections causes many failures and sliding of the implemented parts of the proposed lining type $(50 \mathrm{~cm}$. rubble covered with $12 \mathrm{~cm}$. plain concrete), for these reasons, this type of lining is refused.

e) The presented three suggested alternatives, supported with a quick feasibility study, could be the only possible solutions for the problems of Al-khofoog canal rehabilitation depending on their technical suitability, and cost.

f) According to the feasibility and economic study which was carried out for the three introduced alternative engineering methods, the last one of using walls of the rubble with cement mortar is the best and least expensive alternative, where the cost of implementing one kilometer is estimated at about 10.62 million LE.

\section{REFERENCES}

[1] Sepaskhah, A. and Salemi, H. (2004). "An empirical model for prediction of conveyance efficiency for small earth canals". Iranian Journal of Sciences and Technology, 28, 623-628.

[2] Plusquellec, H. (2019). "Overestimation of benefits of canal irrigation projects: Decline of performance over time caused by deterioration of concrete canal lining". Irrigation and Drainage, 68(3), 383-388. https://doi.org/10.1002/ird.2341.

[3] Merkley, G. (2007). "Irrigation conveyance \& control, flow measurement \& structure design, Lecture Notes BIE 6300. Utah State University, Logan, Utah. http://www.neng.usu.edu/bie/faculty/merkley/

[4] Shivakumar, M.G. (2020). "Performance assessment of irrigation systems". Available online: https://www.icid.org/ china_ppts2018/training_ayp_china2018_5.pdf (accessed on 11 July 2020).

[5] Karantz, D. B., (2007). "Canal lining". Food and Agricultural Organization. Retrieved on 22/12/12 from www.FAO.
[6] Al-Husseini, T. R. (2009). "Optimal lining and seepage analysis of juan canal". A Ph. D. Thesis submitted to the Department of Civil Engineering, College of Engineering, University of AL-Qadissyia.

[7] Soomro, A., Qureshi, A.L., Memon, N.A., and uddin Abro, Z. (2018). "Efficacy of watercourse lining in sindh-A review study in relation with kohistan region". Agric. Sci., 9: 1215-1227.

[8] Zhang, Q., Chai, J., Xu, Z., and Qin, Y. (2017). "Investigation of irrigation canal seepage losses through use of four different methods in hetao irrigation district, China. J." Hydrol. Eng. 22: 1-11.

[9] Snell, M. (2001). "Lining old irrigation canals: thoughts and trials". Irrig. Drain. 50: 139-157.

[10] Eshetu, B. and Alamirew, T. (2018). "Estimation of seepage loss in irrigation canals of tendon sugar estate, Ethiopia". Irrig. Drain. Syst. Eng.,7:3-7.

[11] Xudong H., Xiugui W., Yan Z., Jiesheng H., Liqing Y., Zhifu C. and Feng F. (2020). "An experimental study on concrete and geomembrane lining effects on canal seepage in arid agricultural areas" Water, 12: 2343. www.mdpi.com/journal/wate

[12] Worstell, R. V. (1976). "Estimating seepage losses from canal systems. Journal of the Irrigation and Drainage Division". American Society of Civil Engineers 102 (IR1):137-147.

[13] Swamee, P. K., Mishra G. C. and Chahar B. R. (2000). "Design of minimum seepage loss canal sections". Journal of Irrigation and Drainage Engineering, 126(1): 28-32.

[14] Iqbal, Z., MacLean R. T., Taylor B. D., Hecker F. J and Bennett D. R. (2002). "Seepage losses from irrigation canals in southern Alberta". Canadian Biosystems Engineering 44(1): 21-27.

[15] Cakmak, B., Betribey, M., Yildirim, Y.E. and Kodal, S. (2004). "Benchmarking performance of irrigation schemes: A case study from Turkey". Irrigation and Drainage, 53(2):155-163.

[16] Leigh, E. (2014). "Evaluation of methods for predicting seepage loss rates for the hard-lined irrigation canals of the lower rio grande valley of texas". Master's thesis, Texas A \& M University. Available electronically from https: / /hdl. handle .net/1969.1/152484

[17] Swamee, P. K. (1995). "Optimal irrigation canal sections". Journal of Irrigation and Drainage Engineering, ASCE 121(6): 467-469.

[18] "Meteorological data of west El Minia during the period from 1-1-2020 to 1-1-2021 as documented in the Metrology POWER _ NASA Single Point _ Daily _Date 2020_01_01_2021_01_01_Coordinates 028d36N _030d66E_a3fa2dbf".

\section{Title Arabic:}

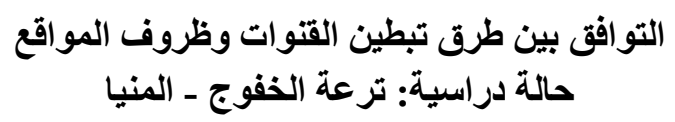

Arabic Abstract:

يعد التوافق بين الطرق المستخدمة في تبطين قنوات الري في التربة ذات الربات الرئي

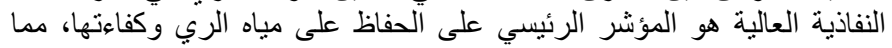

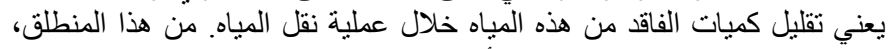

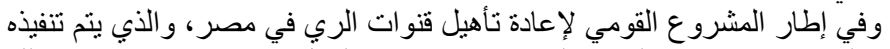

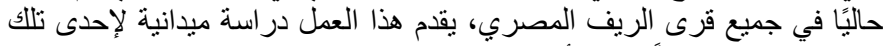

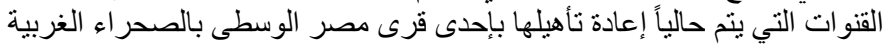

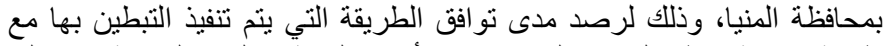

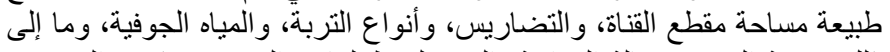

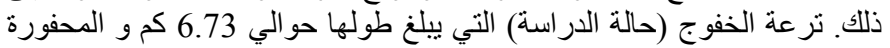

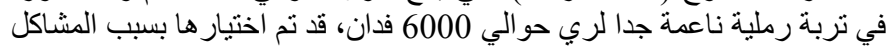

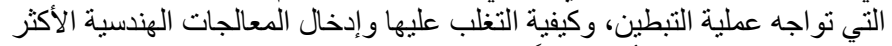

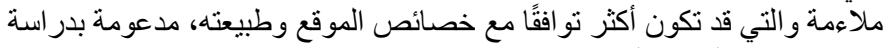
جدوى اقتصادية سريعة.

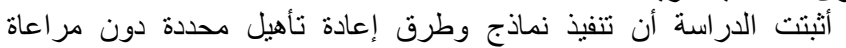

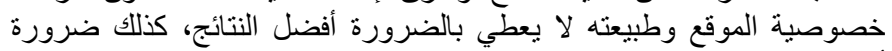

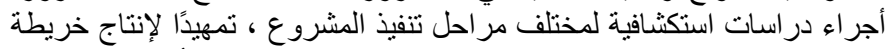

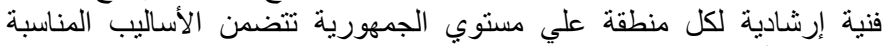
لعمليتي التأهيل و التبطين. 


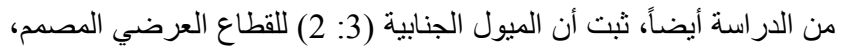

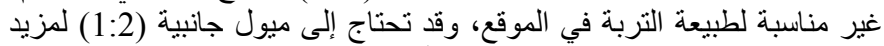

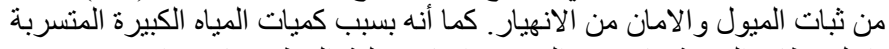

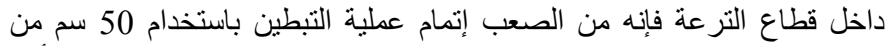

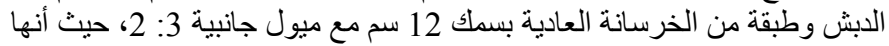

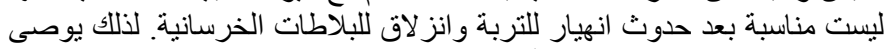

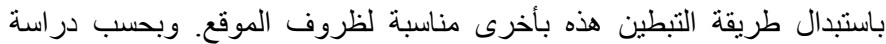

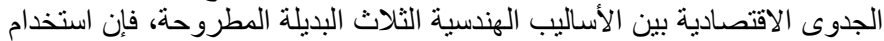

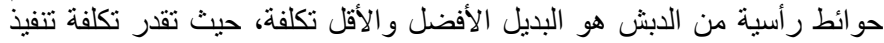
الكيلومتر الو احد منه بنحو 10.62 مليون جنيه. 